\title{
'He Who Would Be a Poet': James K. Baxter's Early Poetry Manuscript Books ${ }^{1}$
}

\author{
Paul Millar
}

He who would be a poet must

See the world in a grain of dust

And beauty in a rainy day.

[Epigraph to Manuscript Book I]

In 1942, the only real clue to sixteen year-old James K. Baxter's future fame could be found in six Manuscript Books full of poems, and he did not show these to many people. As he wrote in a letter to his friend Noel Ginn, 'I was very loath to expose my verse to the private or public eye, as I had sensed early the morbid fear of poetic expression which so many have' (Baxter to Ginn, 12 Feb. 1943). By 1946, when his regular correspondence with Ginn concluded, Baxter had filled a further seven MS Books and was well into his eighth-MS Book XIV. When, in February 1947, MS Book XIV had been filled, the total number of Baxter's poems in final draft was 1025-only seventy-two of these appear in the Collected Poems.

Two decades on, in 1968, Baxter, now up to MS Book XXVIII, ceased keeping a systematic record of his drafts. Evidence suggests that after two years of prolific output in 1966-67 as the University of Otago's Burns Fellow, writing ceased to be Baxter's priority. In some respects he had exhausted himself-looking back he called the Burns Fellowship 'a conditional mistake' that 'hadn't exactly done me in. But my asbestos suit had worn through in a few places' ('The Burns Fellowship', 247). Even before becoming Burns Fellow he had, in 1963, begun examining his role as a writer, and his motivation for writing:

It is the business of a poet, I think, to be destitute as well as honest. He may have money; but he should recognise that it is dirt. He may have prestige; but let him hate it and wear it like an old filthy coat. Then he may be able to stay awake a little better. Love will not harm him, though. It will slice him open like a fish, and hang him by the heels, and let the sun into his private bag of dreams and idiot

Kōtare 2, no. 2 (1999), pp. 27-43. 
ambitions. He will think he is dying when he is just beginning to wake up ('Writing and Existence', 18).

The years of the Burn's Fellowship seemed to Baxter a kind of death. Looking back on the time he remarked that there 'was a bit too much death inside me' and mused, 'I wonder how much of the death was my own and how much came from the fellowship' ('The Burns Fellowship', 246). He appears to have woken to the idea that it was no longer sufficient to go about 'the business of the poet'-as he had defined it in 1963-as if a poet's vocation was simply metaphorical. An inward sense of destitution was not enough; the business of the poet became the prescription for a lifestyle.

I do not find it a coincidence, therefore, that the year Baxter ceased keeping his notebooks was the year he dreamed of a life free of trappings in a commune at Jerusalem on the Whanganui River, 'where the people, both Maori and pakeha, would try to live without money or books, worship God and work on the land' (McKay, 237). Yet even when Jerusalem had become a reality and Baxter was living as simple a life as possible, he could not stop writing: it was a habit that had been well fixed in him almost thirty years earlier. In 1944 he had written to Ginn: 'I have at last discovered that it is more meritorious for me to abstain from writing a poem than to write it' (25 Feb. 1944). At Jerusalem this unshakeable need to write became something of a conundrum. Baxter began making even more explicit associations between poetic activity and death: 'The man called James K. Baxter, who is like a dead body in the ground, swells up and gives off a stink of words' (Jerusalem Daybook, 17) He was unable to reconcile poetry-which he supposed he wrote 'for money and kudos'-with poverty, which was the cornerstone of communal life: 'It is absurd to say I am really a poor man while I keep on putting words together. Words set in order are mental possessions' (ibid).

Many of these 'mental possessions'-Baxter's twenty-eight MS Books, and a substantial amount of loose material-are now in the Hocken Library. According to Howard McNaughton the safe arrival of the notebooks at the Hocken was due to good luck rather than good stewardship:
A few months before he died, James K. Baxter collected all the literary relics he had to hand, put them in a large polythene bag, knotted the neck with string and attached an address label and stamps, and sent the lot by unregistered surface mail to an unsuspecting librarian friend. (62)

Kōtare 2, no. 2 (1999), pp. 27-43. 
The impression gained from this account-particularly if it is read in conjunction with John Weir's comments that 'Baxter's handwriting proved at times to be indecipherable' (The Bone Chanter, 7) and that a number of Baxter's later poems may be lost because they 'were not systematically recorded' (Collected Poems, xxv) -is that Baxter's work habits were as scruffy as his later appearance. For much of his life, however, such was not the case. During the period of his correspondence with Ginn his notebooks exhibit a meticulous attention to detail. In fairness to Weir, though, Baxter's handwriting did become more of a challenge as time progressed, as the (still comparatively legible) draft of 'Obsequy for Dylan Thomas,' from MS Book XX, indicates.

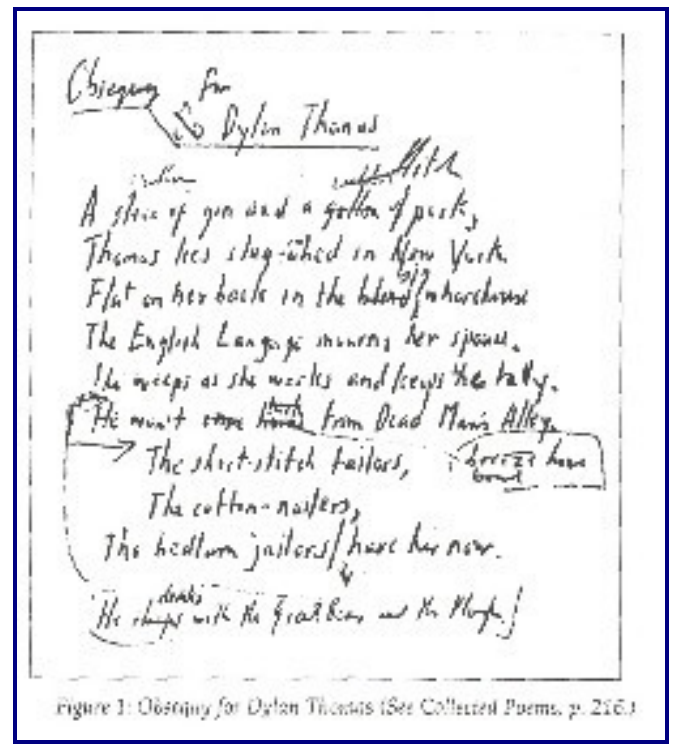

Figure 1: Obsequy for Dylan Thomas (See Collected Poems, p. 216.)

It was only after the publication of Beyond the Palisade (1944) that Baxter began relaxing his standards of draft presentation. These early notebooks were his private publications. It is evident from the care he took in their presentation, and the considerable labour he must have expended, that the first fourteen MS Books were not merely records of poems, they provided the young Baxter with tangible proof that he was indeed a poet. It is an argument supported by the fact that, with the publication of his first book, a marked decline in the attention Baxter lavished on his MS Books becomes immediately evident.

Baxter's first MS Book sets the standard for the thirteen that follow. As we see at Figure 2, MS Book I begins with an inscribed title page. 


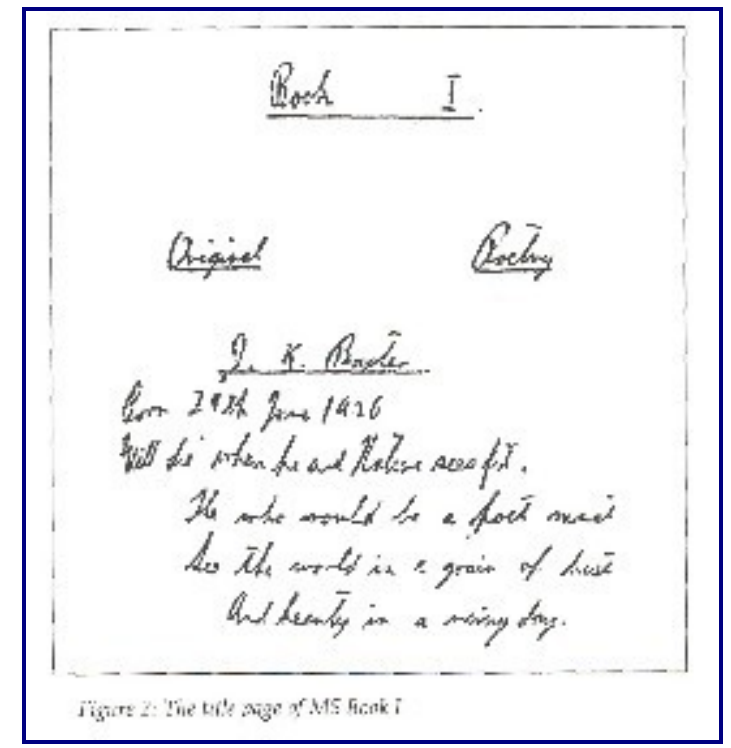

Figure 2: The title page of MS Book I

Weir begins his introduction to Baxter's Collected Poems by quoting this, with the comment 'When he was eleven years old James Keir Baxter wrote the following inscription with a rooster quill on the first page of a new notebook'. Weir's account is problematic on two counts. Firstly, my research suggests that Baxter was close to fourteen when he began recording his poems in his MS Books (see below) and Weir himself argues in his Introduction to The Bone Chanter, that it 'was probably in 1939, at the age of thirteen, that [Baxter] began to collect his early verse into the first of... twenty-eight Manuscript Books' (p.5). Secondly, in MS Book I the lines 'Born $29^{\text {th }}$ June 1926 / Will die when he and Nature sees fit' are written in pencil (unlike the three lines below it which are written in ink, and may have been written by a rooster quill). As late as 1943 Baxter was still making pencil annotations in his early notebooks (see Millar, p.72), and could therefore have been anywhere between thirteen and sixteen when the pencilled inscription was added.

Immediately following the title page is an index of poems, these indexes follow a continuous numbering sequence that runs unbroken from MS Book I to MS Book XIV. What probably began as an attempt to keep track of his cumulative output later proved useful to Baxter as a means of reference when, for example, a poem was a re-write of an earlier poem. ${ }^{2}$ Figure 3 details the numbering sequence and the total number of poems in each MS Book.

Figure 3: Numbering sequence of Baxter's poems and number of poems per MS Book

\section{MS Book Contains Poems Numbered Total}

Kōtare 2, no. 2 (1999), pp. 27-43. 


$\begin{array}{lll}\text { I } & 1-83 & 83 \\ \text { II } & 84-131 & 48 \\ \text { III } & 132-162^{\underline{3}} & 31 \\ \text { IV } & 163-263 & 101 \\ \text { V } & 264-323 & 60 \\ \text { VI } & 324-387 & 64 \\ \text { VII } & 388-460 & 73 \\ \text { VIII } & 461-503 & 43 \\ \text { IX } & 504-569 & 66 \\ \text { X } & 570-651^{4} & 82 \\ \text { XI } & 652-708 & 57 \\ \text { XII } & 709-765^{\underline{5}} & 57 \\ \text { XIII } & 766-855 & 90 \\ \text { XIV } & 856-1025 & 170 \\ & \text { Total } & \mathbf{1 0 2 5}\end{array}$

Next to the poem's sequential number in the index Baxter would enter its title and the number of the page in the MS Book upon which the poem begins. Baxter recalled that the 'poem-writing habit began when I was seven' (The Man on the Horse, 121), $\underline{6}$ but he was almost twice that age when he began systematically recording the final drafts of his poems in his poetry notebooks. Consequently, his first manuscript notebook is different from those that follow in one important respect: it is a retrospective document containing eighty-three poems that Baxter wrote between the ages of seven and fourteen. $\underline{7}$ As the table at Figure 4 indicates, the recorded age of composition remains disordered until around age thirteen, which would support John Weir's estimate that 'it was probably in 1939, at the age of thirteen, that he began to collect his early verse into the first of the twenty-eight Manuscript Books'. However, poem thirty-six ('White are the Clouds'), which was written at fourteen, appears in the midst a number of poems written at thirteen; which may indicate that Baxter was still transcribing his early poems into MS Book I well into 1940, and that he was fourteen before he began entering his poems sequentially.

Figure 4: Poems in MS Book I listed according to Baxter's age at time of composition

$\begin{array}{lll}\begin{array}{l}\text { Age at Time of } \\ \text { Composition } \underline{8}\end{array} & \begin{array}{l}\text { Poem Number in MS } \\ \text { Book I }\end{array} & \begin{array}{l}\text { Number of Poems } \\ \text { Composed }\end{array} \\ \text { Seven } & 51^{\underline{9}} & 2 / 5 \\ \text { Eight } & \mathrm{Nil} & \mathrm{Nil} \\ \text { Nine } & 51 & 1 / 5\end{array}$

Kōtare 2, no. 2 (1999), pp. 27-43. 
Ten

Eleven

Twelve

Thirteen

Fourteen
51

$1-8,12,14^{10}$

9-11, 13

15-35, 37-42

36, 43-50, 52-83 11

Total
$2 / 5$

10

4

27

41

83

In the early MS Books the poems begin immediately following the index (the later books, from MS Book XV on, have no index): every poem begins on a new page; as a rule each poem is headed with the poem's sequential number, a one letter classification (written in pencil) and the poem's title (underlined in pencil); finally, beneath each poem Baxter has written his age at the time of composition (also in pencil). This draft of 'Inspiration', from MS Book II, is typical.

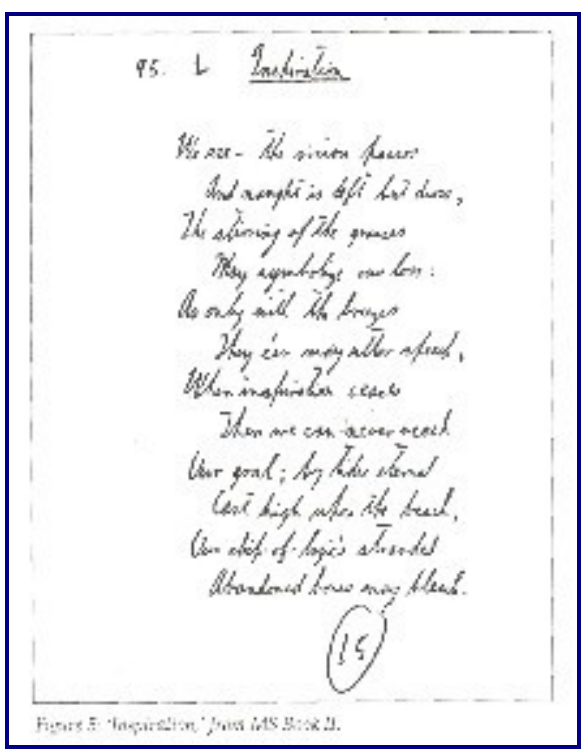

Figure 5: 'Inspiration,' from MS Book II.

Not content with simply transcribing poems into MS Book I, Baxter initially set about keeping a journal (MS Hocken 971/21) in which he described each poem, and the conditions of its production, in some detail. In separate columns he entered the month of composition, the year of composition, the subject of the poem, the metre in which it was written, his assessment of the poem's standard, his age at the time of composition, and, finally, two to three lines of general observations concerning the poem. Consider, for example, poem eight in MS Book I.

Kōtare 2, no. 2 (1999), pp. 27-43. 
Satan's Battle.

'Neath shimmering pools of blackest night

That ne'er let in the noonday light,

There lay the gates of Hell:

'Twas there the devil Prince of Night

Challenged to meet in single fight

That heavenly messenger of Right,

The Angel Gabriel.

[11]

They met, but e'er they fought he saw

Those symbols of Celestial Law,

The Scales, proclaim his foe

Would victor be; He, to withdraw

Was fain; He opened wide his maw

And gave one last and fiendish roar,

Then to his lair did go.

[14]

Baxter made the corresponding journal entry:

Month July; Year 1937; Subject Satan's Battle; Metre Iambic;

Standard Fair; Age 11; General This is taken from Milton's Paradise Lost, and only the first verse was written. At the age of fourteen the author finished it, but "fiendish roar" can scarcely be called a true rhyme to "maw."

However he must have realised the magnitude of the task he was setting himself and decided, quite quickly, that posterity would have to make do without the author's insights—he discontinued his journal having made entries for just twenty-four poems.

Despite the decision to discontinue his journal, Baxter still included a considerable amount of information (detailed above) with the poems in the early MS Books. This information is useful when, for example, it comes to determining the years during which the young Baxter was most active as a poet. Figure 6 gives a summary the poems written up to the age of twenty.

Figure 6: Early Poems, and age at time of composition.

Age at Time of Beginning Composition
Poems by sequential MS Book number
Total Poems

Kōtare 2, no. 2 (1999), pp. 27-43. 
Seven

Eight

Nine

Ten

Eleven

Twelve

Thirteen

Fourteen

Fifteen

Sixteen

Seventeen

Eighteen

Nineteen

Twenty
51 (2 fragments of 5)

$2 / 5$

414 (2 of 4 poems)

$2 / 4$

51 (1 frag.), 414 (1 of 4 poems)

$1 / 5 \& 1 / 4$

51(2 frags.), 414 (1 of 4 poems)

$2 / 5 \& 1 / 4$

$1-8,12,14$

10

9-11, 13, 94

5

15-35, 37-42, 57

28

36, 43-50, 52-56, 58-88

45

89-93, 95-366

277

367-413, 415-568

201

$569-778$

210

779-870

92

871-982

112

983-1025

Total
43 cont. $\underline{13}$

1025

Perhaps the most interesting feature of Baxter's first fourteen MS Books is his classification system. Next to the title of every poem is a single letter 'S', 'L', 'U', 'D', 'N', or the Greek letter ' $w$ ' (note the 'L' in Figure 5). Baxter entered the key to his classification system in the back of MS Book I, as follows:

- $\mathrm{S}$ - sure

- L - likely

- D - doubtful

- U - unlikely

- $\mathrm{N}$ - not included

- w - outside a category

This key is repeated in the rear of 'Book II' with two modifications that hold through to MS Book XIV: 'N' becomes 'not included, (probably)' and the letter ' $w$ ' is dropped. Baxter gives no further information on the criteria by which each category is determined, but from his application of the codes it is possible to infer a relationship that deals with their suitability for publication, combined with his own subjective assessment of each poem's merit.

In addition to the regular coding system described above, Baxter would also make certain cryptic annotations in the index to an MS Book next to the titles of particular poems. These annotations are less easy to decipher although it is possible to make educated guesses about some-for example, poems initialed 'AH' probably indicate poems sent by Baxter to his Aunt Hettie (Hester HurstSeager) who lived in Australia. However the meaning of symbols like a heavy

Kōtare 2, no. 2 (1999), pp. 27-43. 
dot or a star can only be speculated on. There is less mystery surrounding the annotations 'beer' and 'spirits' next to certain poems in MS Book XIII. These poems were written in 1944-45 when Baxter was, by all accounts, drinking heavily: in a letter to Lawrence Baigent written around this time he gives an account of the production of one poem while stimulated by alcohol:
At present I live in the now nervily with a sense of heaviness, mainly because I drank a great deal of spirits three days ago. I had been down at University, was asked to write a new university song, not of the Here we are again... variety. Then called in at the pub, drank a little beer and discussed Hopkins and Chatterton. Met a medical student for whom once before I had written a poem to a girl;- he was delighted to meet me and requested another poem to another girl: gave me dinner: placed me upstairs in an armchair with a continual supply of rum and gin: and waited for the poem. After about 35 minutes and 14 glasses it arrived, good and pithy, epigrammatic I think. He was entirely satisfied and I wandered off to a dance bearing up bravely. $\underline{\underline{14}}$

In addition to the sequential numbering system that runs through all fourteen MS Books, books I to XII also contain one further measure of his poetic output: in the rear of each of these MS Books Baxter has pencilled in a figure that is almost certainly his count of the total number of lines of verse in each book. $\underline{15}$ The cumulative total is, by poem 765 in MS Book XII, quite staggering.

Figure 7: Baxter's Line Count for MS Books I to XII

$\begin{array}{ll}\text { MS Book } & \text { Line Count } \\ \text { I } & 1426 \\ \text { II } & 1474 \\ \text { III } & 759 \\ \text { IV } & 2122 \\ \text { V } & 1380 \\ \text { VI } & 1445 \\ \text { VII } & 1897 \\ \text { VIII } & 861 \\ \text { IX } & 1489 \\ \text { X } & 2087 \\ \text { XI } & 1391 \\ \text { XII } & 2177\end{array}$

Kōtare 2, no. 2 (1999), pp. 27-43. 


\section{Total 18,508}

The care Baxter took with MS Books I to XIV can be taken as an indication of just how highly he valued his 'mental possessions', and how he treated them as private publications: these MS Books cover his juvenile, adolescent, and early adult phases of his development as a poet; they contain all of the poems he sent to his friend Noel Ginn; the poems from Beyond the Palisade; the unpublished collection Cold Spring; and most of the poems from Blow, Wind of Fruitfulness. The fact that the dramatic shift away from inscribed title pages, careful indexing, sequential numbering, a line count, recording of age at the time of composition, and classification of the poem's standard, occurs around 1944-45-the period in which Beyond the Palisade was published-fully supports my belief that once Baxter had actually achieved publication he no longer needed MS Books to prove to himself that he was a poet.

\section{Works Cited}

Baxter, James K. Letter to Noel Ginn. 12 Feb. 1943. McKay Papers. VUW Library. MS Item 28/8.

=. Letter to Noel Ginn. 25 Feb. 1944. McKay Papers. VUW Library. MS Item $28 / 36$

=. Letter to Lawrence Baigent. 4 mar. 1945. McKay Papers. VUW Library. MS McKay 19/3/19.

=. Manuscript notebooks_fair copies. Volumes I-XXVIII. 1937-67. 28 volumes. James K. Baxter Papers. Hocken Library MSS 704/1-28.

I have made particular use of the early MS Books and detail these below. In this list the Hocken manuscript number is followed by the sequential numbers of the poems in each notebook according to Baxter's own numbering system, and, finally, the number of pages containing Baxter's poems:

'Book l'-MS 704/1, contains poems 1 to 83, 119 pages.

'Book II'-MS 704/2, contains poems 84 to 131, 111 pages.

'Book III'-MS 704/3, contains poems 132 to 162, 61 pages. (Notebook 3 also contains five poems by Archibald Baxter.)

'Book IV'-MS 704/4, contains poems 163 to 263, 183 pages.

'Book V'-MS 704/5, contains poems 264 to 323, 111 pages.

'Book VI'-MS 704/6, contains poems 324 to 387, 114 pages.

'Book VII'-MS 704/7, contains poems 388 to 460, 154 pages.

'Book VIII'-MS 704/8, contains poems 461 to 503, 73 pages.

Kōtare 2, no. 2 (1999), pp. 27-43. 
'Book IX'-MS 704/9, contains poems 504 to 569, 90 pages.

'Book X'-MS 704/10, contains poems 570 to 651, 177 pages. (Notebook 10 also contains three poems by Archibald Baxter.)

'Book Xl'-MS 704/11, contains poems 652 to 708, 109 pages.

'Book XII'-Ms 704/12, contains poem 709 to 765, 157 pages.

'Book XIII'-MS 704/13, contains poems 766 to 855, 219 pages.

'Book XIV'-MS 704/14, contains poems 856 to 1025, 284 pages.

'Book XV'-MS 704/15, poems unnumbered, 216 pages.

—. Manuscript notebooks—drafts. 1937-c. 1968. 25 volumes. 'Hocken series MS 975-1-25. In particular:

Notebook, MS 975/1, containing 'Notes on Poetry and Verse.'

Notebook, MS 975/14, titled 'Original Poetry J. Baxter.' This notebook contains drafts of many early poems later transcribed into MS 704/1.

Notebook, MS 971/21, containing Baxter's 'journal' of his early poems.

$=$. Beyond the Palisade. Christchurch: Caxton, 1944.

$=$ Blow, Wind of Fruitfulness. Christchurch: Caxton Press, 1948.

=. 'Writing and Existence.' Education XII.7 (Aug. 1963): 16-19.

$=$. The Man on the Horse. Dunedin: University of Otago Press, 1967.

$=$. 'The Burns Fellowship'. Landfall XXII (1968): 243-7.

$=$. Jerusalem Daybook (Poems and Prose). Wellington: Price Milburn, 1971.

$=$ Collected Poems. Ed. J. E. Weir. Wellington: Oxford University Press, 1981.

$=$ Cold Spring. Ed. Paul Millar. Auckland: Oxford University Press, 1996.

McKay, Frank. The Life of James K. Baxter. Auckland: Oxford UP, 1990.

McNaughton. Howard D. 'Baxter's Strong Ghost.' Landfall 137, 35.1 (Mar. 1981): 62-6.

Millar, Paul. "Spark to a Waiting Fuse": James K. Baxter's Correspondence with Noel Ginn, 1942-46.' Unpublished Dissertation. Wellington: VUW Library, 1996. This paper is based on 'Section Six: Baxter's Early Manuscript Books' of 'Part l: Texts and Contexts' (pp. 60-70).

Weir, J.E.Introduction. The Bone Chanter: Unpublished Poems 1945-72 by James K. Baxter. Wellington: Oxford UP, 1976. 5-8.

-. Introduction. Collected Poems by James K. Baxter. Wellington: Oxford UP, 1981. xxi-xxvii. 


\section{Endnotes}

1 I am grateful to James K. Baxter's literary executor, J. C. Baxter, for permission to reproduce here unpublished and original manuscript material, first included in my doctoral dissertation. In order to preserve the integrity of the tables and diagrams, subsequent footnotes appear as endnotes in this article.

2 An example of this is the poem 'Rain-ploughs': the version printed in Beyond the Palisade (p. 11 and also CP, p. 26) is a revision of the early 'Rain-ploughs' which is poem 320 in MS Book V (see Baxter's letter on pp. 134 for this version). The later, published, version appears as poem 767 in MS Book XIII, where it is simply titled 'Re-casting of 320' (see p. 379).

3 MS Book III also includes transcriptions of five poems written by Archie Baxter: 'Spirits of Harmony, Music and Love,' 'Great Universe, how Vast,' 'Loud calls the voice of Reason,' 'O my Brothers,' and 'Death' (MS Hocken 704/3, pp. 65-71).

4 MS Book $X$ also includes transcriptions of a further three poems by $\underline{\text { Archie }}$ Baxter: 'Simons Town,' 'Burns,' and 'We had no fear... ' (MS Hocken 704/10, following poem 651 on p. 177).

5 MS Book XII also includes one further transcription of a poem by Archie Baxter: 'His voice it is the low vast tone... ' (MS Hocken 704/12 following poem 765 on p. 155).

6 There is a manuscript notebook in the Hocken archive that appears to predate the more formal 'Book I' (Hocken MS 704/1): numbered MS 975/14 and titled 'Original Poetry J. Baxter' this notebook contains drafts of many of the early poems later transcribed into MS Book I.

7 MS Book I is also slightly different in that in the inside back cover Baxter has listed the following terms:

8 The age shown here is the age when the composition of the poem was begun; from time to time Baxter would add to a poem, if he did he would also indicate his age at the time he made the addition.

9 Poem 51 is in fact five 'Fragments of Earlier Poems.' Similarly, a poem numbered 414 in MS Book VII records four other 'Early Poems (written 711)'-see Figure 5.

10 The second verse of Poem 8-'Satan's Battle'-was added when Baxter was 14; while in the five-stanza poem 'The Curse of War' (poem 14) only

Kōtare 2, no. 2 (1999), pp. 27-43. 
the first stanza was written at the age of 11 , with the remaining 4 being added by Baxter when he was 13.

11 The age at which poem 57, 'A Ship is Sailing in the Harbour Mouth' was composed is not clear-it appears to be '14', possibly changed to '13.' Due to the uncertainty, I have attributed to it the same age ('14') as the poems around it.

12 This is my summary of the details of the entry as they appear in the table in MS Hocken 971/21 beneath each (underlined) heading.

13 Poems written while Baxter was still twenty continue on in to MS Book XV, but as Baxter ceased entering his age beneath poems after MS Book XIV it is impossible to say with precision how many more poems were written before he turned twenty-one-although it may be less than 10 if the sixth poem 'Song in June 1947' or 'June Song' (Hocken MS 704/15, p. 7) is an accurate indication of the poem's date.

14 Letter to Lawrence Baigent, 4 Mar. 1945, VUW Library, Wellington, MS McKay 19/3/19.

15 My own count of the lines in MS Books I to XII is not identical to Baxter's, but in all cases it is close enough to strongly support my belief that these numbers are indeed his line count. The variation may occur because I am counting using different criteria-for example, Baxter may have excluded from his count lines taken from earlier poems to be re-used in later ones.

Kōtare 2, no. 2 (1999), pp. 27-43. 